\title{
Observations on Groundwater Contamination with Nitrogen Compounds: A Case Study from Medias town, Sibiu County
}

\author{
Maria Alexandra HOAGHIA ${ }^{1,2^{*}}$, Erika LEVEI ${ }^{1}$, Cecilia ROMAN ${ }^{1}$, Dumitru RISTOIU ${ }^{2}$ \\ ${ }^{1}$ INCDO-INOE 2000, Research Institute for Analytical Instrumentation, 67 Donath, RO-400293, Cluj- \\ Napoca, Romania \\ ${ }^{2}$ Babes-Bolyai University, Faculty of Environmental Science and Engineering \\ Cluj-Napoca, 30 Fantanele, RO-400294, Cluj-Napoca, Romania \\ *Corresponding author: alexandra.hoaghia@icia.ro
}

Bulletin USAMV series Agriculture 74(1)/2017

Print ISSN 1843-5246; Electronic ISSN 1843-5386

DOI 10.15835/buasvmcn-agr: 12653

\begin{abstract}
Worldwide, the groundwater (water well and public spring) is used as drinking water source. The water quality is important due to the possible negative effects on the consumers' health, especially for infants. Nitrogen compounds $\left(\mathrm{NO}_{2} ; \mathrm{NO}_{3}, \mathrm{NH}_{4}^{+}\right)$are present as natural components of the nitrogen cycle and their presence in the groundwater is ubiquitous. But, due to the anthropogenic activities high concentrations of nitrogen compounds are release into the groundwater, thereby the chemical compounds concentrations exceed the maximum allowable concentrations (MACs). The purpose of the present study was to assess the content of nitrogen compounds in groundwater, namely private water wells and public springs used as drinking water sources by the Medias town population. The study results show alarming $\mathrm{NO}_{2}{ }^{-}$and $\mathrm{NO}_{3}{ }^{-}$concentrations; the $\mathrm{NO}_{3}{ }_{3}^{-}$concentrations exceed 5 times the $\mathrm{MAC}$ and $\mathrm{NO}_{2}{ }^{-}$concentrations exceed 3 times the MAC.
\end{abstract}

Keywords: drinking water, groundwater, $\mathrm{NO}_{2} ; \mathrm{NO}_{3}, \mathrm{NH}_{4}^{+}$contamination

\section{INTRODUCTION}

Groundwater is a vital resource, the main source of water supply, especially for people who have no other source of water. Groundwater is a natural, limited, fresh and clean source of water. Nitrogen compounds $\left(\mathrm{NO}_{2}^{-}, \mathrm{NO}_{3}{ }^{-}, \mathrm{NH}_{4}^{+}\right)$are natural resources idem, but the anthropogenic activities are sources of nitrogen compounds in the natural factors (soil $\rightarrow$ groundwater $\rightarrow$ surface water $\rightarrow$ plants $\rightarrow$ human) (Uwah et al., 2009; Belkhiri et al., 2011; Kent and Landon, 2013). Therefore, normal concentrations of nitrogen compounds are exceeded due to anthropogenic activities (agriculture, industry, household activities) (Du et al., 2011, Wick et al., 2012). Nitrate and nitrite are important compounds that sustain and maintain the soil matrix, but high concentrations have a direct and negative impact on groundwater composition. Hence higher concentrations as the maximum admissible concentrations - MACs (Law 311/2004, Order 621/2014) of nitrogen compounds represent a worldwide health problem (Croll and Hayes, 1988, Bru and Pedreno, 2003, Chan, 2011). China, India, SUA, Finland are only a few of the countries with significant nitrogen contamination issues (Salo and Turtola, 2006, Darwish et al., 2011, Chaudhuri 2014). Romania confronts also with high levels of nitrogen compounds, especially in water wells from rural areas (Rowland et al., 2011). The aims of this study were (i) to determine the $\mathrm{NO}_{2}{ }^{-}, \mathrm{NO}_{3}{ }^{-}, \mathrm{NH}_{4}{ }^{+}$pollution status of groundwater and (ii) to assess the quality of water wells from Medias town and vicinity. 


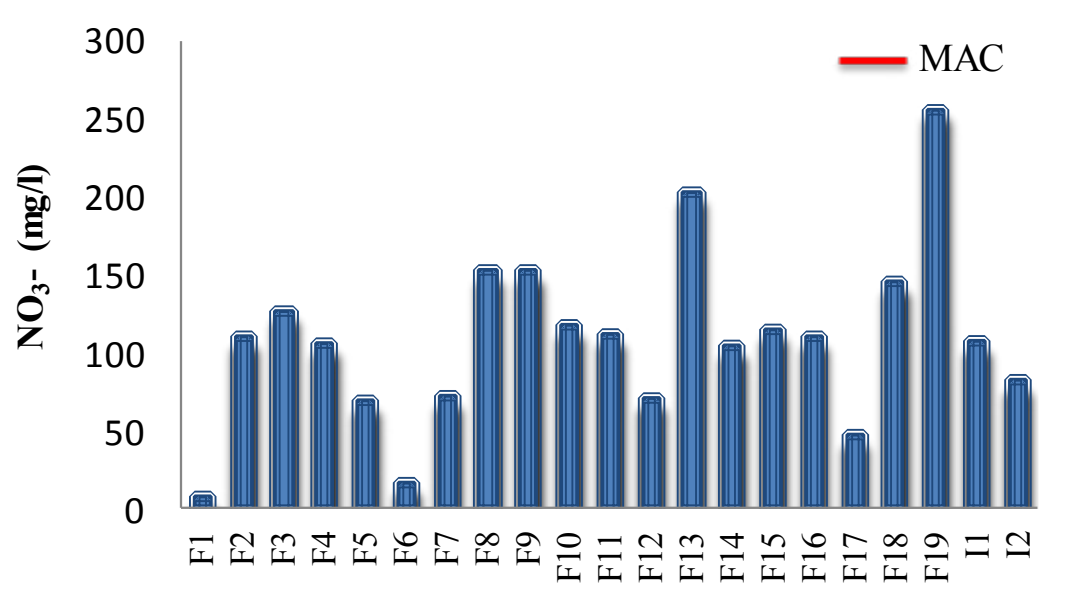

Fig.1. Variation of the $\mathrm{NO}_{3}{ }^{-}$content

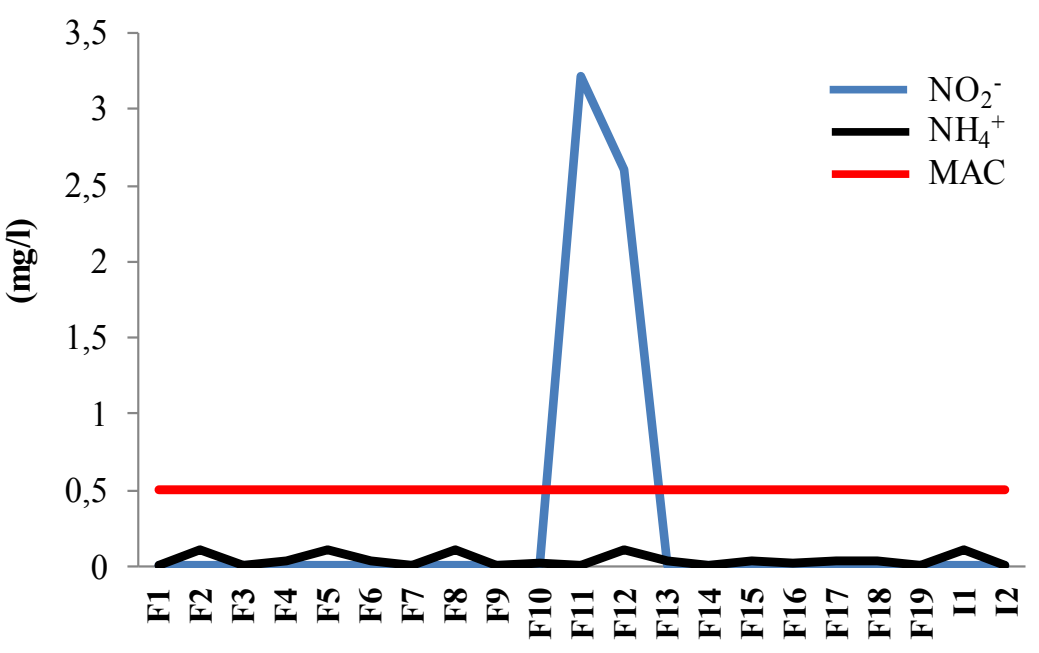

Fig. 2. $\mathrm{NO}_{2}^{-}$and $\mathrm{NH}_{4}{ }^{+}$concentration for the water samples

\section{MATERIALS AND METHODS}

Study area and water sampling

Groundwater samples from private water wells and public springs were collected in the wet season from Medias town and the nearby vicinity. The study area is localized in the southern part of Transylvanian hilly depression; a temperate climate characterize it with an annual average air temperature of $7-8{ }^{\circ} \mathrm{C}$, and $600-700 \mathrm{~mm}$ as the annual precipitations range. The geology structure is represented mainly by interlaid layers of sands, chad, grey marls and smooth lime. Tarnava Mare river (Mures drainage area) is the main surface water source with $221 \mathrm{~km}$ length (Chira and Malacu, 2008) which represents a drinking water source as well.

Groundwater samples were collected from 19 private water wells (F1-F19) and 2 public springs (I1 and I2). For the sampling, hydrophore pumps and buckets were used. The water samples were collected in clean polyethylene bottles and stored at $4^{\circ} \mathrm{C}$ until the chemical analyses.

\section{Analytical methods}

The $\mathrm{NO}_{2}^{-}$and $\mathrm{NO}_{3}^{-}$concentrations were determined by ion chromatography (IC 761 Compact Methrom A.G.), while $\mathrm{NH}_{4}^{+}$as indophenol blue complex was measured by UVVIS spectrometry (Perkin - Elmer Lamba 25). The $\mathrm{pH}$ of the samples was measured by a 350I multiparameter (WTW).

\section{RESULTS AND DISCUSSION}

The high $\mathrm{NO}_{3}^{-}$concentration found shows contamination of all water samples. The $\mathrm{NO}_{2}^{-}$ contents were also high, indicating contamination of 2 samples (F10, F11). The $\mathrm{NO}_{2}^{-}$concentrations exceed 3 times the $\mathrm{MAC}(0.5 \mathrm{mg} / \mathrm{l})$ and $\mathrm{NO}_{3}^{-}$ 

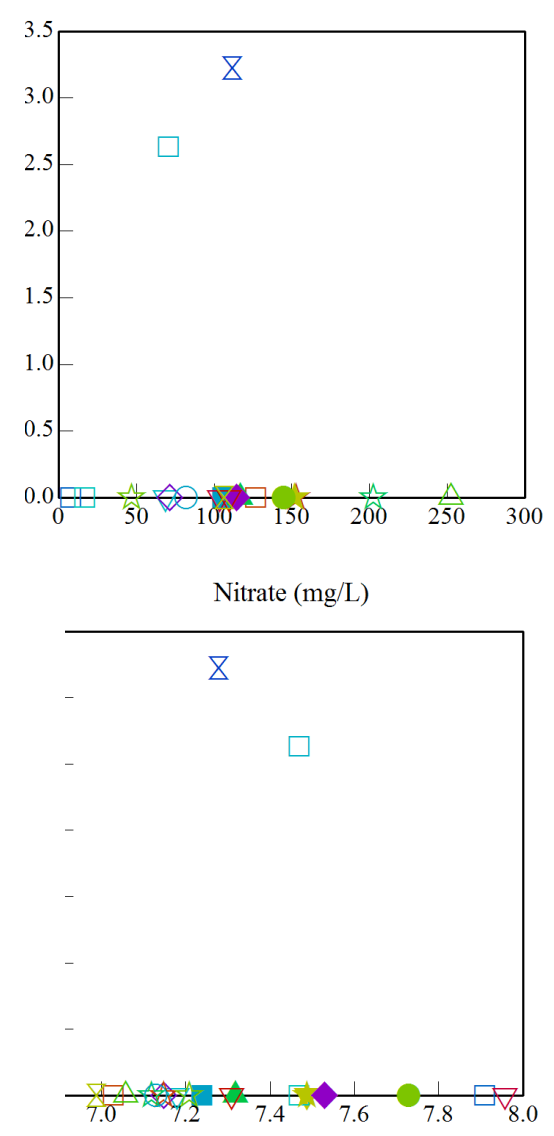

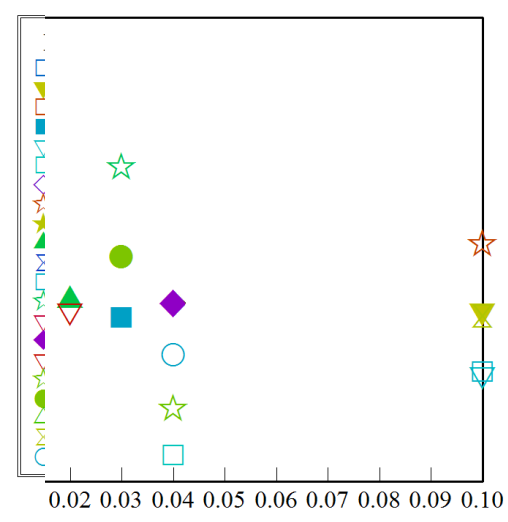

Ammonium (mg/L)

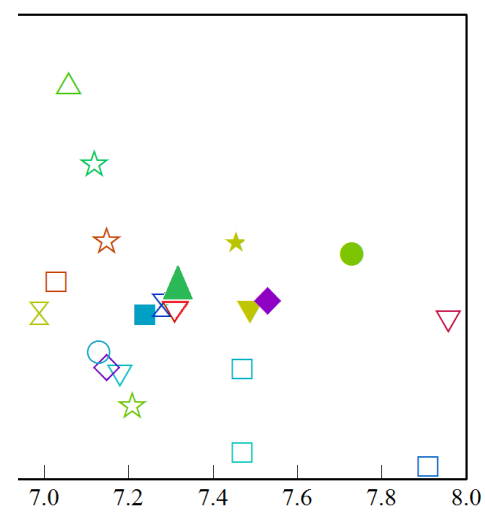

$\mathrm{pH}$

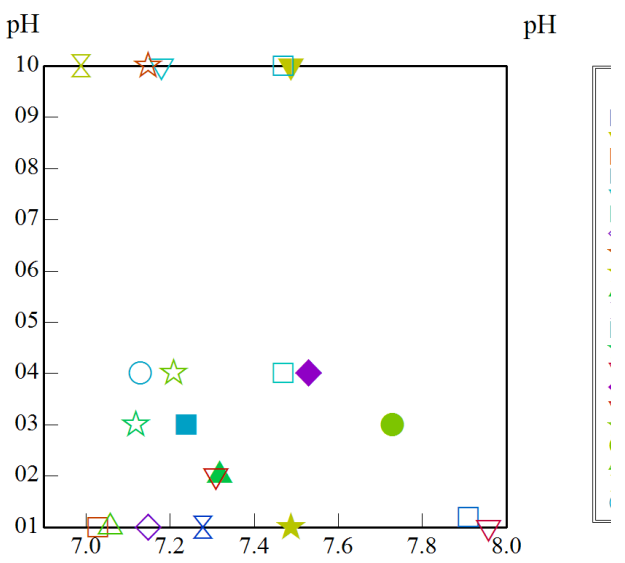

$\mathrm{pH}$

Fig. 3. Representation of nitrogen compounds and pH correlations

concentrations exceed 5 times the MAC (50 mg/l) (Law 311, 2004). All water samples (except F1 and F6) present significant high $\mathrm{NO}_{3}^{-}$concentrations (Figure 1). $\mathrm{NO}_{3}^{-}$values exceed 5 times MAC (Law 311/2014, WHO, 2011).

Ammonium concentrations were bellow the MAC $(0.5 \mathrm{mg} / \mathrm{l})$, as Figure 2 indicates.

Possible sources for the nitrogen compounds are represented by leakeage of waste waters and fecaloid compounds from dry toilets, collecting tanks, cattle house and cattle faeces deposits. An important aspect is the short distance (1-10 m) betweend the pollution and the drinking water sources.

In our samples the dominant concentration is represented by $\mathrm{NO}_{3}$; likewise the variable is significant correlated with the high concentrations which exceed the MAC. 
Cross plots are used to correlate the nitrogen compounds and (Figure 3). Higher $\mathrm{NO}_{2}^{-}$values are observed for the medium $\mathrm{NO}_{3}^{-}$values (between 50-100 mg/l). The highest concentrations of $\mathrm{NH}_{4}{ }^{+}$correlate with the $\mathrm{NO}_{3}^{-}$concentrations and the lowest $\mathrm{NO}_{2}^{-}$values correlate with the lowest $\mathrm{NO}_{3}^{-}$values. The highest $\mathrm{NH}_{4}{ }^{+}$concentrations are measured at groundwater samples characterized with a pH ranging between 7.0 and $7.5 \mathrm{pH}$ units, while the lowest concentrations are scatter between 6.9 and $7.9 \mathrm{pH}$ units; whereas $\mathrm{NO}_{3}$ concentrations are scatter between 6.9 and $7.9 \mathrm{pH}$ units for all groundwater samples.

\section{CONCLUSIONS}

The obtained results demonstrate that, although there are no fertilizers used for the agricultural activities and no industrial activities (in present days), there are still high concentrations of $\mathrm{NO}_{2} ; \mathrm{NO}_{3} ; \mathrm{NH}_{4}^{+}$which characterize the well waters and springs from Medias town and the vicinity. The $\mathrm{NO}_{2}^{-}$and $\mathrm{NO}_{3}{ }^{-}$concentrations exceed the MACs five times as MAC $\left(\mathrm{NO}_{3}{ }^{-}\right)$. Field observations attest a possible pattern regarding the source of high concentrations of nitrogen compounds. Therefore, the septic tanks and collecting tanks are plausible explanations for the high nitrogen compounds concentrations. The studied water samples from Medias town present organic contamination due to the anthropogenic activities.

Acknowledgments: This work was funded by Core Program (PN 16.40.02.01) under the support of ANCSI, and by IMPAACT project (91BM/2017) under the support of CNCS -UEFISCDI, Capacities Program.

\section{REFERENCES}

1. Belkhiri L, Boudoukha A, Mouni L (2011). A multivariate statistical analysis of groundwater chemistry data. International Journal of Environmental Resources 5(2):537-544.

2. Bru R, Pedreño M (2003). Method for the production of resveratrol in cell cultures, PCT patent WO 03/062406.

3. Sindelar JJ, Milkowski AL (2012). Human safety controversies surrounding nitrate and nitrite in the diet. Nitric Oxide 26:259-266.

4. Chan T (2011). Vegetable-borne nitrate and nitrite and the risk of methaemoglobinaemia. Toxicology Letters 200:107-108.

5. Chaudhuri S, Ale S (2014). Long term (1960-2010) trends in groundwater contamination and salinization in the
Ogalla aquifer in Texas. Journal of Hydrology 513:376390.

6. Chira C, Malacu A (2008). Biodiversity and paleoecology of the Miocene calcareous nannoplankton from Sibiu area (Transylvania, Romania). Acta Palaeontologica Romaniae 6:17-28.

7. Croll BT, Hayes CR, 1988. Nitrate and water supplies in the United Kingdom. Environmental Pollution 50 (1-2):163187.

8. Darwish T, Atallah T, Francis R, Saab C, Jomaa I, Shaaban A, Sakka H, Zdruli P (2011). Observations on soil and groundwater contamination with nitrate: A case study from Lebanon-East Mediterranean, Agricultural Water Management 99:74-84.

9. Du L, Zhao T, Zhang C, An Z, Wu Q, Liu B, Li P, Ma M (2011). Investigations in nitrate pollution of soil, groundwater and vegetable from three typical farmlands in Beijing Region, China. Agricultural Sciences in China 10(3):423-430.

10. Hoaghia MA, Roman C, Ristoiu D, Popita G, Tanaselia C (2013). Assessing of water quality pollution indices for heavy metal contamination. A study case from Medias City ground waters, Agriculture - Science and Practice, 3-4:87-88.

11. Kent R, Landon MK (2013). Trends in concentrations of nitrate and total dissolved solids in public supply wells of the Bunker Hill, Lytle, Rialto, and Colton groundwater subbasins, San Bernardino County, California: Influence of legacy land use. Science of the Total Environment 452453:125-136.

12. Rowland H A L, Omoregie EO, Millot R, Jimenez C, Mertens J, Baciu C, Hug SJ, Berg M (2011). Geochemistry and arsenic behaviour in groundwater resources of the Pannonian Basin (Hugary and Romania). Applied Geochemistry 26:117.

13. Salo T, Turtola SE (2006). Nitrogen balance as an indicator of nitrogen leaching in Finland. Agriculture, Ecosystems and Environment 133:98-107.

14. Uwah EI, Abah J, Ndahi NP, Ogugbuaja VO (2009). Concentration levels of nitrate and nitrite in soils and some leafy vegetables obtained in Maiduguri, Nigeria. Journal of Applied Sciences in Environmental Sanitation $3(4): 233-244$.

15. Wick K, Heumesser C, Schmid E (2012). Groundwater nitrate contamination. Journal of Environmental Management 111:178-186.

16. *** WHO, 2011, Guidelines for drinking water quality fourth edition. Online source: http://www. who. int / water_sanitation_health/publications/2011/dwq guidelines/en/.

17. *** Law 311, 2004, that improves and complements Law 458 from 2002 regarding the quality of drinking water. Online source: http://www.rowater.ro/dacrisuri/ Documente\%20Repository/Legislatie/gospodarirea\%20 apelor/LEGE\%20311_28.06.2004.pdf.

18. ${ }^{* * *}$ Order 621,2014 , regarding the approval of threshold values for groundwater from Romania. Online source: http://lege5.ro/Gratuit/gqydcmbxgm/ordinul-nr-6212014-privind-aprobarea-valorilor-de-prag-pentru-apelesubterane-din-romania. 